\begin{tabular}{|c|l|}
\hline Title & $\begin{array}{l}\text { Evaluation of paleoenvironment using terpenoid biomarkers in lignites and plant fossil from the Miocene Tokiguchi } \\
\text { Porcelain Clay Formation at the Onada mine, T aji imi, central Japan }\end{array}$ \\
\hline Author(s) & Sawada, Ken; Nakamura, Hideto; A rai, Takaaki; Tsukagoshi, Minoru \\
\hline Citation & $\begin{array}{l}\text { International Journal of Coal Geology, 107, 78-89 } \\
\text { https://doi.org/10.1016/.Coal.2012.10.013 }\end{array}$ \\
\hline Issue Date & 2013-03-01 \\
\hline Doc URL & http://hdl.handle.net/2115/52672 \\
\hline Type & article (author version) \\
\hline File Information & IJCG-Sawada2013_HUSCAP.pdf \\
\hline
\end{tabular}

Instructions for use 


\title{
Evaluation of paleoenvironment using terpenoid biomarkers in lignites and plant fossil from the Miocene Tokiguchi Porcelain Clay Formation at the Onada mine, Tajimi, central Japan
}

\author{
Ken Sawada $^{\text {a*}}{ }^{\text {, Hideto Nakamura }}{ }^{\text {a }}$, Takaaki Arai ${ }^{a}$, Minoru Tsukagoshi ${ }^{b}$ \\ ${ }^{a}$ Department of Natural History Sciences, Faculty of Science, Hokkaido University, N10W8, Kita-ku, \\ Sapporo 060-0810, Japan \\ ${ }^{\mathrm{b}}$ Osaka Museum of Natural History, Nagai Park 1-23, Osaka 546-0034, Japan \\ *Corresponding author; Tel.: +81-11-706-2733; Fax: +81-11-746-0394 \\ E-mail address: sawadak@mail.sci.hokudai.ac.jp (K. Sawada).
}

\begin{abstract}
We investigated terpenoid biomarkers in muds from lignite seams, clays from porcelain clay beds that slightly contain lignite, and from a conifer cone macrofossil from the Miocene Tokiguchi Porcelain Clay Formation of the Tokai Group in central Japan, as well as extant cones. The $n$-alkanes, $n$-alkanols (suberin origin), diterpenoids (conifer origin), hopanoids (bacteria origin) and steroids were mainly present in the lignite-containing muds and clays. On the other hand, the diterpenoids, triterpenoids (angiosperm origin), hopanoids and steroids were detected as major component in the conifer cone macrofossil. In addition, the diterpenoids were mainly detected in the extant conifer cones. The low hopane isomer ratios and the detection of biosterols are confirmed to be immature in the lignite, sediment and macrofossil in the formation. The stanol / sterol ratio values of the lignite-containing muds and clays are much higher than that of the macrofossil. The higher ratios in lignite-containing muds and clays are possibly attributed to enhanced microbial reduction of organic matter under reduced condition in the swampy environments. A large amount of angiosperm-derived triterpenoids detected in the conifer cone macrofossil are considered as contaminants in the sample from sedimentary organic particles originated from detrital waxes of angiosperms. Such contamination might occur by migration of organic compounds within sediment after deposition. The angiosperm-derived polar terpenoids may be hardly affected by contamination by migration of organic matter from the adjacent sediments because these are less abundant in the conifer macrofossil. Thus, it is suggested that the polar terpenoid biomarkers are more reliable as paleochemotaxonomic and paleovegetation indicators.
\end{abstract}


Keywords: lignite, plant macrofossil, polar terpenoid biomarker, fluvial system, swampy environment, contamination

\section{Introduction}

Coal and lignite beds are important geological, paleontological and geochemical samples that can provide essential information for terrestrial paleoenvironment and paleoclimate as well as paleobotany. Recently, biomarker investigation of coal and lignite have been performed, and contributed to the understanding of coal-forming paleoenvironment (e.g., Bechtel et al., 2002; 2008; Hatcher and Clifford, 1997; Ketola et al., 1987; Quirk et al., 1984; Stefanova and Simoneit, 2008). In particular, terrestrial higher plant-derived biomarkers such as terpenoids have been suggested to be useful as chemotaxonomic indicators and paleovegetation proxies (Hautevelle et al., 2006; Lockheart et al., 2000; Nakamura et al., 2010; Otto and Simoneit, 2001; Stefanova and Simoneit, 2008; van Aarssen et al., 2000). However, functionalized terpenoid biomarker, which is frequently contained in immature samples, is less applicable for the assessment of paleoenvironment and paleobotany because fewer compounds have been identified. Indeed, only few works report the presence of polar terpenoids in immature lignite and plant materials (Otto and Simoneit, 2001; Otto et al., 2002; Simoneit et al., 2003; Stefanova and Simoneit, 2008; Stefanova et al., 2005). Detailed identification of polar terpenoids will help in refining paleoenvironmental and paleobotanical assessments for immature lignite, woody sediment, peat and plant fossil.

The Tokiguchi Porcelain Clay Formation of the Tokai Group, distributed in Tajimi area of central Japan, has been known to have intercalated lignite beds, from which well-preserved plant macrofossils were found (Saneyoshi et al., 2000; Todo Collaborative Research Group, 1999;

Tsukagoshi, 2011). It is noteworthy that this formation contains immature sedimentary material and fossils, despite the fact that it is a Miocene sediment deposited in the central Japan arc, which is an active tectonic region. Depositional environment of this formation was reconstructed (Saneyoshi et al., 2000; Todo Collaborative Research Group, 1999), but maturation and preservation of lignite and plant fossil have not been systematically evaluated. Sawada et al. (2008) studied hydrolysable alkyl compounds from resistant macromolecules in Pliocene plant macrofossil from the Tokai Group for evaluating paleochemotaxonomy and diagenetic process of the plant fossils.

In this study, we analyzed lignite-containing mudstones, claystones and a plant macrofossil collected from the Miocene Tokiguchi Porcelain Clay Formation of the Tokai Group. Biomarkers extracted from the plant macrofossil are compared with those extracted from extant plants. The objectives of this study are, 1) to evaluate maturity level and preservation processes of immature lignite and plant fossil, 2) to assess plant source and depositional environment of the lignite beds, and 3 ) to examine applicability of functionalised terpenoid biomarker as paleochemotaxonomic and paleovegetation indicators from immature lignite and plant fossil.

\section{Geological setting}


The Tokai Group is located in the eastern part of the middle Miocene to Pleistocene Second Setouchi Supergroup, which is widely distributed in central and western Japan. The group around Tajimi City of central Japan composed of middle Miocene to Pliocene fluvial sediments, and is divided into the Tokiguchi Porcelain Clay Formation and Toki Sand and Gravel Formation (Fig. 1 and Fig. 2; Todo Collaborative Research Group, 1999). The Tokiguchi Porcelain Clay Formation is 10 - $30 \mathrm{~m}$ thick, and contains mostly sand and mud as well as some lignite seams. The Toki Sand and Gravel Formation comprises mainly gravel, which is more than $40 \mathrm{~m}$ thick. Ages of the Tokiguchi Porcelain Clay Formation and Toki Sand and Gravel Formation were determined by fission track dating from tuff layers of the Oroshi, Hida, Ohhari, and Nakatsugawa I and II (Fig. 2; Yoshida et al., 1997). The sedimentary basin around Tajimi City is made up of small basement block less than 20 $\mathrm{km}^{2}$ in the area which may indicate very low rate of sedimentation with no acceleration of subsiding since ca. 2.5 Ma.

Paleoenvironmental setting of the late Miocene Tokiguchi Porcelain Clay Formation at Tajime area was mainly a fluvial environment near the mountain slope, as reconstructed by investigation of sedimentary facies and paleobotanical assemblage for plant macrofossils (Saneyoshi et al., 2000). In this formation of the Okumura-Seram mine, which is part of the Onada mine, of Tajimi City, seven sedimentary facies such as flood flow $(\mathrm{Fl})$, swamp $(\mathrm{C}$ and $\mathrm{Fm})$ and backswamp (Fr) were recognized (Fig. 3; Saneyoshi et al., 2000), and plant macrofossils of conifer cones and diaspores as well as angiosperm seeds and fruit were found (Saneyoshi et al., 2000; Tsukagoshi, 2011). These macrofossils were immature and well-preserved in morphology.

\section{Materials and methods}

\subsection{Samples}

We collected muds from the lignite seams of OSC-1 and OSC-4 in the Miocene Tokiguchi Porcelain Clay Formation at the Okumura-Seram mine (Onada mine) of Tajimi City in central Japan (Figs. 3 and 4). The lignite seams of OSC-1 and OSC-4 are composed of lignites originated from woody bough, twig and trunk with matrix of mud, and we sampled the muds where the fragments of woody bough and twig are mainly contained. Also, clays were collected from porcelain clay beds of OSC-2 and OSC-3 (Figs. 3 and 4). These clay samples hardly contain lignite and plant-derived particles. A conifer cone macrofossil Pinus fujiii was collected from the sand and conglomerate bed above the OSC-3 bed of the Miocene Tokiguchi Porcelain Clay Formation (Saneyoshi et al., 2000; Figs. 3 and 5). Paleobotanical description of this fossil was reported by Miki (1941), and this is thought to be an extinct species. The age of the Tokiguchi Porcelain Clay Formation was estimated to be presumably ca. 10 - 12 Ma by fission track dating (Yoshida et al., 1997). In addition, the extant cones of Pinus rigida and Pinus thunbergii, which may be affiliated to P. fujiii, were collected from the Nagai Botanical Garden in Osaka City, Japan, in November 2002 (Fig. 5).

\subsection{Analytical methods}


The lignite-containing muds and clays, as well as a conifer cone macrofossil were grinded to a fine powder in an agate mortar, while extant pine cones were cut to fine tips with pruning shears. Free compounds were extracted from powder samples of lignite-containing sediments and a fragment sample of cone macrofossil with distilled water, methanol (MeOH) and dichloromethane (DCM) as described by Sawada et al. (1996; 2008). For extant cones, the tips were steeped in flasks with $\mathrm{MeOH} / \mathrm{DCM}(3 / 1, \mathrm{v} / \mathrm{v})$ overnight to extract the free compounds as Sawada et al. (2008). As internal standard, $\mathrm{d}_{50}$-tetracosane was added after extraction. Separation of lipids was achieved by adding distilled water to the combined extracts and then DCM layer was siphoned out and passed through an anhydrous $\mathrm{Na}_{2} \mathrm{SO}_{4}$ column. The extract was dried in a rotary evaporator and then redissolved in hexane. The lipid contained in the hexane extract was then passed through a silica gel column (95\% activated), and the aliphatic hydrocarbon (F1), aromatic hydrocarbon (F2), ketone-ester (F3) and polar lipid (F4) fractions were eluted with hexane, hexane-toluene $(3: 1 \mathrm{v} / \mathrm{v})$, hexane-ethyl acetate $(9: 1 \mathrm{v} / \mathrm{v})$ and ethyl acetate-MeOH $(1: 1 \mathrm{v} / \mathrm{v})$, respectively. After these elutions, the $\mathrm{d}_{50}$-tetracosane was added to the polar fraction as an external standard. The polar fraction was silylated $\left(60^{\circ} \mathrm{C}, 1 \mathrm{~h}\right)$ using $N, O$-bis(trimethylsilyl) trifluoroacetamide (BSTFA, Wako) at $60^{\circ} \mathrm{C}$.

Identification of the lipids was performed on gas chromatography (GC) / mass spectrometry (MS) with Hewlett Packard 6890N a capillary GC (30m x 0.25 mm i.d. DB-5HT fused silica column, J\&W Scientific) directly coupled to a Hewlett Packard inert XL MSD (quadrupole mass spectrometer, electron voltage $70 \mathrm{eV}$, emission current $350 \mu \mathrm{A}$, mass range $\mathrm{m} / \mathrm{z}$ 50-600 in $1.3 \mathrm{~s}$ ). The GC was programmed as follows: $60{ }^{\circ} \mathrm{C}$ for $5 \mathrm{~min}, 60-250{ }^{\circ} \mathrm{C}$ at $10{ }^{\circ} \mathrm{C} / \mathrm{min}, 250-320{ }^{\circ} \mathrm{C}$ at $3{ }^{\circ} \mathrm{C} / \mathrm{min}$ and $320^{\circ} \mathrm{C}$ for $20 \mathrm{~min}$. Compounds were identified on the basis of mass spectra and relative retention times in comparison with library data (NIST05) and the literature.

Quantification of the lipids was conducted on a Hewlett Packard 6890 capillary gas chromatograph equipped with a flame-ionization detector (FID), capillary column and temperature program used were the same as GC/MS conditions.

\section{Results and discussion}

Concentrations of apolar and polar lipid biomarkers in the samples are shown in Table 1 and Table 2, respectively. The $n$-alkanes, diterpenoid and hopanoid hydrocarbons were mainly present in aliphatic hydrocarbon fraction (F1) in lignite-containing muds of OSC-1 and OSC-4, and clays of OSC-2 and OSC-3 (Fig. 6a). A large amount of diterpanes such as fichitelite (a7) (6.76 - $8.40 \mu \mathrm{g} / \mathrm{g}$ dry sediment), which is derived from conifer (Otto and Wilde, 2001), are detected as the most dominant components in these muds and clays. The $n-\mathrm{C}_{20}-n-\mathrm{C}_{30}$ alkanes are detected, and their odd-carbon number predominance are hardly observed. The $n$-alkane maximum is at $\mathrm{C}_{25}$ for all sediment samples. These trends of the $n$-alkanes resemble those of gymnosperm fossils as reported by Nakamura et al. (2010). Hopanoid hydrocarbons detected in the sediments are hopenes including hop-17(21)-ene (a21) and hopanes including $\mathrm{C}_{31} 17 \alpha(\mathrm{H})$-hopanes (homohopanes; a26 and a27).These biomarkers have been shown to derive from bacteria, and therefore, this result indicates 
that these muds and clays were affected by microbial activity. The $\mathrm{C}_{29}-\mathrm{C}_{31} 17 \beta(\mathrm{H}), 21 \beta(\mathrm{H})$-hopanes (a25, a28 and p30), which are usually contained in very low maturity samples, are present as trace compounds in lignite-containing muds. In aromatic hydrocarbon fractions (F2) of all sediment samples, aromatic diterpenoid hydrocarbons including dehydroabietane (b4) and retene (b8) are identified (Table 1). The aromatic diterpanes detected are formed from abietic acid, which is a major constituent of conifer (Otto and Wilde, 2001).

The $n$-alkanol, diterpenoic acid and steroid are mainly detected in polar fraction (F4) of the lignite-containing muds and clays (Table 2 and Fig. 6b). The highest concentrations of diterpenoic acid are observed for dehydroabietic acid (p10; 6.63 - $20.35 \mu \mathrm{g} / \mathrm{g}$ of dry sediment). An even-carbon number predominance is clearly observed for the $n-\mathrm{C}_{22}-n-\mathrm{C}_{28}$ alkanols (maximum is at $\mathrm{C}_{26}$ homologue) in all sediment samples. This indicates that these $n$-alkanols are originated from plant wax and/or $n$-alkanol units constituting suberin polymer (Pollard et al., 2008). Noticeably, biosteroids such as $\beta$-sitosterol (p25) and campesterol (p23) are detected in all sediment samples (Table 2 and Fig. 6b). Thus, it is confirmed that these sediments are much immature. Also, $\mathrm{C}_{29}$ stanol, stigmastanol (p26), are identified, and the stanol is known to be commonly formed from biosteroid during early diagenesis (Nishimura, 1977). Terpenoid biomarkers detected in apolar and polar fractions of all sediment samples are derived from conifer and bacteria, while no angiosperm-derived biomarkers are identified.

The des-A type triterpenes and hopanoid hydrocarbons were detected as major components in aliphatic hydrocarbon fraction (F1) in the fossil P. fujiii (Fig. 7a). Although this cone macrofossil is from conifer plant i.e. gymnosperm group, several des-A type lupenes, oleanenes and ursenes, which are of angiosperm origin, are abundantlydetected in the chromatogram of the macrofossil. While conifer-derived diterpanes such as fichitelite are rather minor components of the extract. Bacterial biomarkers of hopanoid hydrocarbons, hop-17(21)-ene, $\mathrm{C}_{29}-\mathrm{C}_{31} 17 \beta(\mathrm{H}), 21 \beta(\mathrm{H})$-hopanes and homohopanes, are present in the fossil.

Angiosperm-derived aromatic triterpenoid hydrocarbons including 8, 14-secooleanane (b9) and 24, 25-dinorlup-1, 3, 5-triene (b10 and b11) are identified as the most dominant components in aromatic hydrocarbon fractions (F2) of a fossil P. fujiii sample (Table 2 and Fig. 7b). These aromatic triterpenoids are intermediate compounds of the progressive aromatization of angiosperm triterpenoids reaction pathway proposed by Tan and Heit, (1981). Conifer-derived aromatic diterpenes, dehydroabietane and retene, are also identified as major component in F2 of the fossil extract.

The diterpenoic acid, triterpenoic acid and steroid are mainly detected in polar fraction (F4) of the fossil P. fujiii (Table 2 and Fig. 7c). Coniferous bioditerpenoid, abietic acid, is abundantly detected, and its concentration is the highest $(258.29 \mu \mathrm{g} / \mathrm{g})$. Dehydroabietic acid which corresponds to the major component of the lignite samples is also a major component of the macrofossil. We also found several diterpenoid acids that have abietane (e.g. 9, 10-secodehydroabietic acid (p1 and p3) and 7-oxodehydroabietic acid (p14)) and pimarane (e. g. isopimaric acid; p6) skeletons in F4. 
Angiosperm-derived polar triterpenoids, 30-norlupanol (p15) and 3-oxolupanoic acid (p27), are also identified. Utilizing mass spectroscopy the carbon skeleton of the 3-oxolupanoic acid has been identified but the position of the carboxylic group cannot be determined (Fig. 7d). At the opposite than what has been observed for F1 and F2 in which these apolar triterpenoids are predominant; they are less abundant in $\mathrm{F} 4$. The $\mathrm{C}_{29}$ stanol (stigmastanol) and biosteroids such as $\beta$-sitosterol and campesterol that likely derived from plant wax and suberin, are identified in the fossil (Table 2 and Fig. 7c). This suggests that fossils have been preserved in immature sediment.

We compared the biomarker compositions in extant $P$. rigida and $P$. thunbergii with the one of the macrofossil $P$. fujiii. Chromatograms of F4 and concentrations of biomarker compounds from the extant cones are shown in Fig. 8 and Table 2, respectively. No terpenoids can be detected in the apolar fractions of F1 and F2. Dehydroabietic acid (p10, p16, p17, p22) and 7-oxodehydroabietic acid (p14) are detected as the most dominant compounds, and unexpectedly, coniferous bioditerpenoid of abietic acid are also detected in only trace amount in $P$. rigida and $P$. thunbergii samples. The diterpenoids that detected in both fossil and extant samples are pimaric acid isomers (p4 and p5), isopimaric acid (p6), abieta-6, 8, 11, 13-tetraenoic acid (p8), dehydroabietic acid (p10) and 7-oxodehydroabietic acid (p14). On the other hand, it is found that secodehydroabietic acid (p1 and p3), isopimar-8-ene-18-oic acid (p2), pimaranoic acids (p7 and p9) and unknown diterpenoid acids (p12 and p13) are identified only in the fossil $P$. fujiii. This suggests that these compounds may be altered after deposition during diagenesis. The unknown diterpenoid acids (p13) have similar structure than dehydroabietic acid, since ion peaks at $\mathrm{m} / \mathrm{z} 239$ and $\mathrm{m} / \mathrm{z} 372$ exist in their mass spectra (Figs. 9a and 9b). In addition, the unknown diterpenoid (p17) identified in only extant conifer cone samples is possibly a compound that derived from dehydroabietic acid; the molecular ion $(\mathrm{m} / \mathrm{z} 418)$ and base peak $(\mathrm{m} / \mathrm{z}, 285)$ corresponds to those $(\mathrm{m} / \mathrm{z} 372$ and $\mathrm{m} / \mathrm{z} 239)$ of dehydroabietic acid plus 46 , respectively, in its mass spectra (Fig. 9c). We confirm that compounds detected in extant cone samples are conifer-derived diterpenoids, that is, no angiosperm-derived triterpenoids are detected, although these compounds cannot be unequivocally identified.

The $\mathrm{C}_{31}$ hopane isomer ratios of $22 \mathrm{~S} /(22 \mathrm{~S}+22 \mathrm{R})$ are calculated to estimate the maturity levels of the organic matter in the lignite-containing muds and clays, and fossil from the Tokiguchi Porcelain Clay Formation at the Okumura-Serum mine. As shown in Fig. 10, these ratios are ranging from 0.11 to 0.15 , and confirm that the samples reach a maturation level of lignite. In addition to the detection of biosterols, it can be proved that the lignite and fossil in the Miocene Tokiguchi Porcelain Clay Formation are much immature. Moreover, it can be seen that such retarded maturity of these lignites and fossils are rare if we consider the fact that the Miocene sediment was commonly experienced significant diagenetic processes in an active tectonic region such as central Japan.

Values of the stanol/sterol ratios of the samples are shown in Fig. 10. The stanol/sterol ratio values of the lignite-containing muds of OSC-1 and OSC-4 (0.92 - 0.96) are significantly lower than those of clays of OSC-2 and OSC-3 (1.43 - 1.84). Moreover, the stanol / sterol ratio of the fossil $P$. fujiii has a much lower value (0.48), and that of extant $P$. rigida and $P$. thunbergii is nearly zero 
(0.01). It was reported that the stanol/sterol ratio values increased with sediment depths in lacustrine sediments and peat sequences, and the values might change because of degradation and microbial hydrogenation of biosterols (Andersson and Meyers, 2012, Nishimura and Koyama, 1977). Thus, this value reflects degree of alteration and/or degradation of biosterol in early diagenetic stage. For example, ratio values between ca. 1 and 2 in the lignite-containing muds and clays in our study are similar or slightly higher than those of the deeper layers $(180 \mathrm{~cm}$ depth) of the Holocene peat sequence in the Eastern European Russian Arctic (Andersson and Meyers, 2012), so that the diagenetic levels of lignite-containing sediments in the Onada mine might be similar to those in modern sediments at the depths of several meters. However, it should be interpreted that variations of the stanol/sterol ratios can be attributed to environmental condition rather than the level of diagenetic alteration. Previous studies demonstrated that the stanol was derived directly from an organism (Nishimura and Koyama, 1977) or that the sterol was converted to stanol at the early stages of diagenesis, and that stanol conversion reaction might occur by microbial reduction (hydrogenation) in the sediment-water interface and anoxic water column of marine and lacustrine environments (Nishimura, 1977; Gagosian et al., 1980). More recently, Bertrand et al. (2012) reported that the stanol/sterol ratios in sediments varied by the environmental change from swamp to pond, and the variation was primarily controlled by the proportion of autochthonous and allochthonous contribution of organic matter and by the redox potential in sediment. According to the relationship between conversion to stanol and redox condition, the highest stanol/sterol ratio values in clays of OSC-2 and OSC-3 are possibly attributed to enhanced microbial reduction of organic matter under reduced (anoxic) condition. By the analysis of sedimentary facies, the depositional environments of the clay beds of OSC-2 and OSC-3, and the lignite seams of OSC-1 and OSC-4 are evaluated to be backswamp and swamp, respectively (Fig. 3; Saneyoshi et al., 2000). The swampy environment is characterized by a high stanol/sterol ratio value as reported by Bertrand et al. (2012). It is predicted that deposition of very fine sediments such as clay results in tight packing of sedimentary matter within the sediment, and the occurrence of an anoxic condition. In the lignite seams of OSC-1 and OSC-4, organic matter might be also preserved under a reduced condition, resulting in high stanol / sterol ratio values. On the other hand, the lower stanol / sterol ratio value of the fossil P. fujiii is resulting from the suppression of microbial reduction under more oxic conditions and the higher contribution of allochthonous organic matter. Indeed, the macrofossil was contained in the sand and conglomerate beds, in which sedimentary facies is debris flow facies (Fig. 3; Saneyoshi et al., 2000). Thus, it is presumed that organic matter constituted the macrofossil experienced microbial oxidation rather than microbial reduction under oxic condition in coarse sediment given by debris flow.

The lignite-containing muds and clays are characterized by the predominance of long-chain $\left(\mathrm{C}_{22}\right.$ - $\mathrm{C}_{28}$ ) $n$-alkanols with even carbon numbers (Fig. 6b). It was found that plant roots were contained in the lignite seams (OSC-1 and OSC-4) and clay beds (OSC-2 and OSC-3), especially OSC-2 bed, in swampy environments by sedimentological investigation (Sanetoshi et al., 2000). Plant root is mainly composed of resistant macromolecules such as suberin, which is thought to be mainly 
composed of $n$-alkanols monomers containing an even carbon numbers (Pollard et al., 2008). Previously our study reported that possible suberin-derived $\mathrm{C}_{22}-\mathrm{C}_{30} n$-alkanols were detected as major hydrolysable compounds from plant macrofossils in the Tokai Group, central Japan (Sawada et al., 2008). The long-chain $n$-alkanols detected in the lignite-containing sediments are free compounds, but these compounds might be the products released from suberin macromolecule by biodegradation during early diagenesis. In addition, it was reported that the free $n$-alkanol was significantly originated from plant root in peatland, China (Huang et al., 2011). Thus, the predominance of the long-chain $n$-alkanols can be explained by the autochthonous supply of these compounds by biodegradation of suberins and/or free lipids derived from plant roots.

Coniferous diterpenoids including fichitelite and dehydroabietane in apolar fractions and dehydroabietic acid in polar fractions are detected as the major components in the lignite-containing muds and clays. No angiosperm-derived terpenoids are identified in the sediment samples. Thus, the biomarker composition of these sediments strongly suggests that conifer, especially species of Pinus, contributed significantly to the Tokiguchi Porcelain Clay Formation. However, plant macrofossils of angiosperm seeds and fruit were found from this formation at the Okumura-Serum mine (Saneyoshi et al., 2000; Tsukagoshi, 2011). Thus, no detection of angiosperm biomarkers from the lignite seams and clay beds is possibly resulting from the selective degradation of angiosperm-derived organic matter in the swampy environment rather than the absence of angiosperm vegetation around the depositional area.

Unexpectedly, we identify several angiosperm-derived triterpenoid hydrocarbons including des-A type triterpenes in aliphatic hydrocarbon fraction (F1), aromatic triterpenoids in aromatic hydrocarbon fraction (F2), as well as norlupanol and oxolupanoic acid in polar fraction (F4) from the conifer cone macrofossil P. fujiii (Fig. 7). Conifer-derived diterpenoids such as fichitelite in apolar fractions are minor component. It is likely that the diterpenoids can be indigenous compounds of the macrofossil. However, the triterpenoids are considered as contaminants in the sample from sedimentary organic particles originated from detrital waxes of angiosperms. Plant organic mass including the fossil P. fujiii in the sand and conglomerate bed might be transported with mixing of gymnosperm and angiosperm plant particles by debris flow. After the deposition, bioterpenoids in the plant particles were rapidly converted to the terpenoid hydrocarbons with the occurrence of A-ring degradation and/or aromatization in the skeletons by microbial oxidation under oxic conditions in the coarse sediment as mentioned above. The apolar terpenoid hydrocarbons are thought to be more easily migrated within the sediment and to be more efficiently attached to organic particles. Thus, the contamination might occur by migration of organic compounds within sediment after deposition rather than by mixing of sedimentary particles during transport and deposition. This suggestion can be supported by the fact that the angiosperm terpenoids are mainly observed as apolar compounds in the conifer cone macrofossil. On the other hand, there has been a report of major amounts of bioterpenoids such as $\alpha$-amyrin and friedeline in conifer shoot fossils from the Miocene Clarkia Formation and attributed them to migration from leaves (Otto et al., 2005). However, 
angiosperm-derived polar terpenoids are less abundant in the polar fraction of the conifer cone macrofossil in our study, so that these terpenoids may be hardly affected by contamination due to migration of organic matter from the adjacent sediments. Thus, it is suggested that the polar terpenoid biomarkers are more reliable as paleochemotaxonomic and paleovegetation indicators. However, unequivocal identification of such polar terpenoids is difficult, and there are many terpenoids with unknown structures. In the future, systematic investigation for detailed identification of polar terpenoids will be necessary.

\section{Conclusions}

Terpenoid biomarkers are analyzed in muds from lignite seams, clays from porcelain clay beds that slightly contain lignite and a conifer cone macrofossil from the Miocene Tokiguchi Porcelain Clay Formation of the Tokai Group. The biomarker results from the cone macrofossil are discussed by comparison with those of extant cones. We conclude that:

1. The $n$-alkanes, $n$-alkanols (suberin origin), diterpenoids (conifer origin), hopanoids (bacteria origin) and steroids were mainly present in the lignite-containing muds and clays. On the other hand, the diterpenoids, triterpenoids (angiosperm origin), hopanoids and steroids were detected as major components in the cone macrofossil. In addition, the diterpenoids are mainly detected in the extant conifer cones.

2. The low hopane isomer ratios and the detection of biosterols are confirmed to be rarely immature in the lignite-containing muds and clays, and macrofossil in the Miocene Tokiguchi Porcelain Clay Formation, despite of its deposition in an active tectonic region such as central Japan.

3. The stanol/sterol ratios of the lignite-containing muds and clays are much higher than that of the macrofossil. The higher stanol / sterol ratios in lignite-containing muds and clays are possibly attributed to enhanced microbial reduction of organic matter under reduced condition in the swampy environments. The lower stanol/sterol ratio of a macrofossil is resulting from the suppression of microbial reduction under more oxic conditions and the higher contribution of allochthonous organic matter in coarse sediments given by debris flow.

4. A large amount of angiosperm-derived triterpenoids detected in the conifer cone macrofossil are considered as contaminants in the sample from sedimentary organic particles originated from detrital waxes of angiosperms. Such contamination might occur by migration of organic compounds within sediment after deposition rather than by mixing of sedimentary particles during transport and deposition.

5. The angiosperm-derived polar terpenoids may be hardly added as contaminants by migration of organic matter from the adjacent sediments because these are less abundant in the conifer macrofossil. Thus, it is suggested that the polar terpenoid biomarkers are more reliable as paleochemotaxonomic and paleovegetation indicators, although systematic investigation for detailed identification of polar terpenoids is necessary. 


\section{Acknowledgements}

We are grateful to two anonymous reviewers for constructive comments. The study was supported in part by Grants-In-Aid Nos.16740291, 18684028 and 23540542 (to K. S.) from the Ministry of Education, Culture, Sports, Science and Technology of Japan.

\section{References}

Andersson, R. A., Meyers, P. A., 2012. Effect of climate change on delivery and degradation of lipid biomarkers in a Holocene peat sequence in the Eastern European Russian Arctic. Organic Geochemistry, 53, 63-72.

Bechtel, A., Gratzer, R., Sachsenhofer, R. F., Gusterhuber, J., Lücke, A., Püttmann, W., 2008. Biomarker and carbon isotope variation in coal and fossil wood of Central Europe through the Cenozoic. Palaeogeography, Palaeoclimatology, Palaeoecology 262, 166-175.

Bechtel, A., Sachsenhofer, R.F., Kolcon, I., Gratzer, R., Otto, A., Püttmann, W., 2002. Organic geochemistry of the lower Miocene Oberdorf Lignite (Styrian Basin, Austria); its relation to petrography, palynology and the palaeoenvironment. International Journal of Coal Geology 51, 31-57.

Bertrand, O., Mansuy-Huault, L., Montargès-Pelletier, E., Losson, B., Argant, J., Ruffaldi, P., Etienne, D., Garnier, E., Dezileau, L., Faure, P., Michels, R., 2012. Molecular evidence for recent land use change from a swampy environment to a pond (Lorraine, France). Organic Geochemistry 50, $1-10$.

Gagosian, R.B., Smith, S.O., Lee, C., Farrington, J.W., Frew, N.M., 1980. Steroid transformation in recent marine sediments. In: Douglas, A.G., Maxwell, J.R. (Eds.), Advances in Organic Geochemistry 1979, Pergamon Press, Oxford, pp. 407-419.

Hatcher, P.G., Clifford, D.J., 1997. The organic geochemistry of coal: from plant materials to coal. Organic Geochemistry 27, 251-274.

Hautevelle, Y., Michels, R., Malartre, F., Trouiller, A., 2006. Vascular plant biomarkers as proxies of palaeoflora and palaeoclimatic changes at the Dogger / Malm transition of Paris Basin (France). Organic Geochemistry 37, 610-625.

Huang, X., Wang, C., Zhang, J., Wiesenberg, G.L.B., Zhang, Z., Xie, S., 2011. Comparison of free lipid compositions between roots and leaves of plants in the Dajiuhu Peatland, central China. Geochemical Journal 45, 365-373.

Ketola, M., Luomala, E., Pihlaja, K., Nyrönen, T., 1987. Composition of long chain fatty compounds and sterols of four milled peat samples from Finnish peat lands. Fuel 66, 600- 606.

Lockheart, M. J., van Bergen P. F., Evershed, R. P., 2000. Chemotaxonomic classification of fossil leaves from the Miocene Clarkia lake deposit, Idaho, USA based on $n$-alkyl lipid distributions and principal component analyses. Organic Geochemistry 31, 1223-1246.

Miki, S., 1941. On the change of flora in Eastern Asia since Tertiary Period (I). The clay or lignite beds flora in Japan with special reference to the Pinus trifolia beds in Central Hondo. Japanese 
Journal of Botany 11, 237-303.

Nakamura, H., Sawada, K., Takahashi, M., 2010. Aromatic terpenoid biomarkers in the Cretaceous and Paleogene angiosperm fossils from Japan. Organic Geochemistry 41, 975-980.

Nishimura, M., Koyama, T., 1977. The occurrence of stanols in various living organisms and the behavior of sterols in contemporary sediments. Geochimica et Cosmochimica Acta 41, 379-385.

Nishimura, M., 1977. The geochemical significance in early sedimentation of geolipids obtained by saponification of lacustrine sediments. Geochimica et Cosmochimica Acta 41, 1817-1823.

Otto, A., Simoneit, B. R. T., 2001. Chemosystematics and diagenesis of terpenoids in fossil conifer species and sediment from the Eocene Zeitz Formation, Saxony, Germany. Geochimica Cosmochimica et Acta 65, 3505-3527.

Otto, A., Wilde, V., 2001. Sesqui-, di-, and triterpenoids as chemosystematic markers in extant conifers - a review. Botanical Reviews 67, 141-238.

Otto, A., White, J.D., Simoneit, B.R.T., 2002. Natural product terpenoids in Eocene and Miocene conifer fossils. Science 297, 1543-1545.

Otto, A., Simoneit, B.R.T., Rember, W.C., 2005. Conifer and angiosperm biomarkers in clay sediments and fossil plants from the Miocene Clarkia Formation, Idaho, USA. Organic Geochemistry 36, 907-922.

Quirk, M.M., Wardroper, A.M.K., Wheatley, R.E., Maxwell, J.R., 1984. Extended hopanoids in peat environments. Chemical Geology 42, 25- 43.

Pollard M., Beisson F., Li Y., Ohlrogge J. B., 2008. Building lipid barriers: biosynthesis of cutin and suberin. Trends in Plant Science 13, 236-246.

Saneyoshi, M., Nakayama, K., Tsukagoshi, M., 2000. Depositinal processes of plant material assemblages in fluvial sediments: examples from plant megafossils in the Miocene Tokiguchi Porcelain Clay Formation at Onada mine in Tajimi, central Japan. Earth Science (Chikyu Kagaku) 54, 127-143. (In Japanese).

Sawada, K., Handa, N., Shiraiwa, Y., Danbara, A., Montani, S., 1996. Long-chain alkenones and alkyl alkenoates in the coastal and pelagic sediments of the northwest North Pacific, with special reference to the reconstruction of Emiliania huxleyi and Gephyrocapsa oceanica ratios. Organic Geochemistry 24, 751-764.

Sawada, K., Arai, T., Tsukagoshi, M., 2008. Compositions of resistant macromolecules in fossil dry fruits of Liquidambar and Nyssa (Pliocene, central Japan). Organic Geochemistry 39, 919-923.

Simoneit, B.R.T., Otto, A. Wilde, V., 2003. Novel phenolic biomarker triterpenoids of fossil laticifers in Eocene brown coal from Geiseltal, Germany. Organic Geochemistry 34, 121-129.

Stefanova, M., Simoneit, B.R.T., 2008. Polar aromatic biomarkers of Miocene-aged Chukurovo resinite and correlation with a progenitor macrofossil. International Journal of Coal Geology 75, 166-174.

Stefanova, M., Oros, D.R., Otto, A., Simoneit, B.R.T., 2002. Polar aromatic biomarkers in the Miocene Maritza-East lignite, Bulgaria. Organic Geochemistry 33, 1079-1091. 
Tan, Y.L., Heit, M., 1981. Biogenic and abiogenic polynuclear aromatic hydrocarbons in sediments from two remote Adirondack lakes. Geochimica et Cosmochimica Acta 45, 2267-2279.

Todo Collaborative Research Group., 1999. Fault bounded inland basin of multiple blocks: an example from the sedimentary basin of the Tokai Group around Tajimi City in Gifu Prefecture, central Japan. Earth Science (Chikyu Kagaku) 53, 291-306. (In Japanese)

Tsukagoshi, M., 2011. Recent progress in paleobotanical and geological studies of Pinus trifolia flora. Japanese Journal of Historical Botany 19, 15-24.

van Aarssen, B. G. K., Alexander, R., Kagi, R. I., 2000. Higher plant biomarkers reflect palaeovegetation changes during Jurassic times. Geochimica Cosmochimica et Acta 64, 1417-1424.

Yoshida, S., Makinouchi, T.,Danbara, T., 1997. Fission track ages of the Lower Tokai Group. Monthly Report of Geological Survey of Japan (Chicho Geppou) 48, 497-510. (In Japanese). 
Table 1 Data of apolar biomarkers such as diterpenoids and triterpenoids in sediments from lignite seams and porcelain clay beds, and a conifer cone fossil (Pinus fujiii) from a sand and conglomerate bed in the Onada mine of Tajimi City, central Japan.

\begin{tabular}{|c|c|c|c|c|c|c|c|c|}
\hline \multirow[t]{2}{*}{ No. } & \multirow[t]{2}{*}{ Compounds } & \multirow[t]{2}{*}{ Type } & \multirow[t]{2}{*}{ Origin } & \multicolumn{5}{|c|}{ Concentrations ( $\mu \mathrm{g} / \mathrm{g}$ dry sediment or fossil) } \\
\hline & & & & OSC-1 & OSC-2 & $\mathrm{OSC}-3$ & OSC-4 & Fossil P. fujiiii \\
\hline \multicolumn{9}{|c|}{ Apolar aliphatic fraction } \\
\hline a1 & Norpimarane? & $D$ & G & 0.67 & 0.11 & 0.04 & 0.79 & 0.24 \\
\hline a2 & Norpimarane? & $D$ & G & 0.61 & 0.14 & 0.05 & 0.69 & n.d. \\
\hline a3 & 19-Norisopimarane & $\mathrm{D}$ & $G$ & 2.10 & 0.93 & 0.53 & 3.67 & 0.44 \\
\hline a4 & Norabietane & $\mathrm{D}$ & $G$ & 1.00 & 0.70 & 0.45 & 1.75 & n.d. \\
\hline a5 & 18-Norisopimarane & $\mathrm{D}$ & G & 1.75 & 1.02 & 0.85 & 2.44 & 0.61 \\
\hline a6 & Unknown diterpane & $D$ & G & 0.86 & 0.49 & 0.28 & 0.87 & 0.25 \\
\hline a7 & Fichitelite (Norabietane) & $\mathrm{D}$ & G & 8.40 & 6.85 & 6.76 & 7.33 & 1.17 \\
\hline a8 & Isopimarane & $\mathrm{D}$ & G & 0.99 & 0.47 & 0.22 & 0.86 & n.d. \\
\hline a9 & Abietane & D & $G$ & 0.08 & 0.06 & 0.02 & 0.11 & n.d. \\
\hline a10 & $16 \beta(\mathrm{H})$-Phyllocladane & $\mathrm{D}$ & $G$ & 0.07 & 0.05 & n.d. & 0.15 & 0.40 \\
\hline a11 & Des-A lup-18-ene & DT & $A$ & n.d. & n.d. & n.d. & n.d. & 0.43 \\
\hline a12 & Des-A olea-9(10),13(18)-diene & DT & $A$ & n.d. & n.d. & n.d. & n.d. & 2.68 \\
\hline a13 & Des-A lup-9-ene & DT & A & n.d. & n.d. & n.d. & n.d. & 1.69 \\
\hline a14 & Des-A lupane & DT & $A$ & n.d. & n.d. & n.d. & n.d. & 2.25 \\
\hline a15 & Des-A ursadiene? & DT & A & n.d. & n.d. & n.d. & n.d. & 0.70 \\
\hline a16 & Des-A ursene? & DT & $A$ & n.d. & n.d. & n.d. & n.d. & 3.21 \\
\hline a17 & Des-A ursadiene? & DT & A & n.d. & n.d. & n.d. & n.d. & 0.37 \\
\hline a18 & Des-A ursene? & DT & $A$ & n.d. & n.d. & n.d. & n.d. & 0.94 \\
\hline a19 & $22,29,30$-Trisnorhopane & $T$ & $B$ & 0.25 & 0.22 & 0.23 & 0.23 & 0.21 \\
\hline a20 & Dinorhopene & T & $\mathrm{B}$ & 0.12 & n.d. & 0.03 & 0.10 & 0.17 \\
\hline a21 & Hop-17(21)-ene & T & $\mathrm{B}$ & 0.23 & 0.06 & 0.08 & 0.15 & 1.89 \\
\hline a22 & Norhopene isomer & $\mathrm{T}$ & $\mathrm{B}$ & 0.24 & 0.07 & 0.06 & 0.16 & 0 \\
\hline a23 & $17 \alpha(\mathrm{H}), 21 \beta(\mathrm{H})$-Hopane & $\mathrm{T}$ & $\mathrm{B}$ & 0.03 & 0 & 0 & 0.02 & 0 \\
\hline a24 & Neohop-13(18)-ene & $\mathrm{T}$ & $\mathrm{B}$ & 0.01 & n.d. & n.d. & 0.02 & 0.14 \\
\hline a25 & $17 \beta(\mathrm{H}), 21 \beta(\mathrm{H})-30$-Norhopane & $\mathrm{T}$ & $\mathrm{B}$ & 0.15 & n.d. & n.d. & 0.13 & 0.14 \\
\hline a26 & $22 \mathrm{~S} 17 \alpha(\mathrm{H}), 21 \beta(\mathrm{H})$-Homohopane & $\mathrm{T}$ & $B$ & 0.04 & 0 & 0.02 & 0.03 & 0.17 \\
\hline a27 & $22 \mathrm{R} 17 \alpha(\mathrm{H}), 21 \beta(\mathrm{H})$-Homohopane & $\mathrm{T}$ & $\mathrm{B}$ & 0.26 & 0.10 & 0.12 & 0.18 & 1.31 \\
\hline a28 & $17 \beta(H), 21 \beta(H)$-Hopane & $\mathrm{T}$ & $B$ & 0.03 & 0 & 0 & 0.02 & 0 \\
\hline a29 & Homomoretane & $\mathrm{T}$ & $\mathrm{B}$ & 0.02 & n.d. & n.d. & 0.02 & 0 \\
\hline a30 & $17 \beta(\mathrm{H}), 21 \beta(\mathrm{H})$-Homohopane & $\mathrm{T}$ & $\mathrm{B}$ & 0.07 & 0 & 0 & 0.04 & 0.17 \\
\hline \multicolumn{9}{|c|}{ Aromatic fraction } \\
\hline b1 & 19-Norabietatriene & $D$ & G & 0.05 & n.d. & n.d. & 0.06 & 0.92 \\
\hline b2 & 18-Norabietatriene & $\mathrm{D}$ & G & 0.19 & 0.22 & 0.11 & 0.12 & 5.92 \\
\hline b3 & 10,18-Dinorabieta-8,11,13-triene & $\mathrm{D}$ & G & 0.04 & n.d. & n.d. & 0.03 & 1.01 \\
\hline b4 & Dehydroabietane & $\mathrm{D}$ & G & 0.04 & 0.10 & 0.07 & 0.02 & 1.06 \\
\hline b5 & $1,2,3,4$-Tetrahydroretene & $\mathrm{D}$ & $G$ & 0.10 & 0.42 & 0.40 & 0.19 & 3.55 \\
\hline b6 & Simonellite & $\mathrm{D}$ & G & 0.01 & n.d. & n.d. & n.d. & 0.19 \\
\hline b7 & 1-methyl-10,18-dinorabieta-8,11,13-trier & $\mathrm{D}$ & $G$ & 0.04 & 0.07 & 0.12 & 0.04 & 0.64 \\
\hline b8 & Retene & $\mathrm{D}$ & $G$ & 0.08 & 0.19 & 0.22 & 0.08 & 2.07 \\
\hline b9 & $8,14-S e c o o l e a n a n e$ & $T$ & $A$ & n.d. & n.d. & n.d. & n.d. & 1.14 \\
\hline b10 & 24,25 -Dinoroleana-1,3,5(10),12-tetraen $\epsilon$ & $\mathrm{T}$ & $A$ & n.d. & n.d. & n.d. & n.d. & 14.89 \\
\hline b11 & 24,25 -Dinorlup-1,3,5-triene & $\mathrm{T}$ & $\hat{A}$ & n.d. & n.d. & n.d. & n.d. & 20.54 \\
\hline
\end{tabular}

n. d.: not detected. Type: D: Diterpene, DT: Des-A triterpene, T: Triterpene.

Origin: A: Angiosperm, B: Bacteria, G: Gymnosperm 
Table 2 Data of polar biomarkers such as diterpenoids, triterpenoids and steroids in sediments from lignite seams and porcelain clay beds, and a conifer cone fossil (P. fujiii) from a sand and conglomerate bed in the Onada mine of Tajimi City, central Japan, and extant conifer cones (Pinus rigida and Pinus thunbergii), cultivated the Nagai Botanical Garden of Osaka City, Japan.

\begin{tabular}{|c|c|c|c|c|c|c|c|c|c|c|}
\hline \multirow[t]{2}{*}{ No. } & \multirow{2}{*}{ Compounds } & \multirow[t]{2}{*}{ Type } & \multirow[t]{2}{*}{ Origin } & \multicolumn{3}{|c|}{ Concentrations ( $\mu \mathrm{g} / \mathrm{g}$ dry sediment) } & \multirow[b]{2}{*}{ OSC-4 } & \multicolumn{3}{|c|}{ Concentrations ( $\mu \mathrm{g} / \mathrm{g}$ dry fossil or extant plant) } \\
\hline & & & & OSC-1 & OSC-2 & OSC-3 & & Fossil P. fujiii & Extant $P$. rigida & Extant $P$. thunbergii \\
\hline \multicolumn{11}{|c|}{ Polar fraction } \\
\hline $\mathrm{p} 1$ & $9,10-$ Secodehydroabietic acid? & D & G & n.d. & n.d. & n.d. & n.d. & 8.12 & n.d. & n.d. \\
\hline p2 & Isopimar-8-ene-18-oic acid & D & G & n.d. & n.d. & n.d. & n.d. & 8.71 & n.d. & n.d. \\
\hline p3 & $9,10-$ Secodehydroabietic acid & D & G & n.d. & n.d. & n.d. & n.d. & 10.46 & n.d. & n.d. \\
\hline p4 & Pimaric acid (isomer A) & D & G & n.d. & 1.55 & 0.28 & n.d. & 28.37 & 101.21 & 104.29 \\
\hline p5 & Pimaric acid (isomer B) & D & G & n.d. & n.d. & n.d. & n.d. & 11.20 & 138.88 & 200.26 \\
\hline p6 & Isopimaric acid & D & G & n.d. & n.d. & n.d. & n.d. & 11.80 & 51.49 & 504.70 \\
\hline p7 & Pimar-8-ene-18-oic acid & D & G & n.d. & n.d. & n.d. & n.d. & 6.51 & n.d. & n.d. \\
\hline p8 & Abieta-6,8,11,13-tetraenoic acid & D & G & n.d. & n.d. & n.d. & n.d. & 25.91 & 129.51 & 52.99 \\
\hline p9 & Pimaran-18-oic acid & D & $G$ & n.d. & n.d. & n.d. & n.d. & 32.25 & n.d. & n.d. \\
\hline p10 & Dehydroabietic acid & D & $G$ & 20.35 & 6.63 & 7.78 & 10.32 & 224.78 & 1230.29 & 1285.11 \\
\hline p11 & Abietic acid & D & G & n.d. & 2.41 & 1.98 & 1.24 & 258.29 & n.d. & n.d. \\
\hline p12 & Unknown compound A & D & $G$ & n.d. & n.d. & n.d. & n.d. & 15.95 & n.d. & n.d. \\
\hline p13 & Unknown compound B & D & G & n.d. & n.d. & n.d. & n.d. & 84.49 & n.d. & n.d. \\
\hline p14 & 7-Oxodehydroabietic acid & D & G & n.d. & 1.73 & 0.85 & 1.74 & 20.38 & 1150.70 & 588.33 \\
\hline p15 & 30-norlupanol & $T$ & $A$ & n.d. & n.d. & 0.12 & n.d. & 13.67 & n.d. & n.d. \\
\hline p16 & Dehydroabietic diacid? & D & G & n.d. & n.d. & n.d. & n.d. & n.d. & 43.45 & 26.01 \\
\hline p17 & Dehydroabietic diacid? & D & G & n.d. & n.d. & n.d. & n.d. & n.d. & 779.10 & 383.72 \\
\hline p18 & Unknown hydroxy diterpenoic acid A & D & $G$ & n.d. & n.d. & n.d. & n.d. & n.d. & 152.92 & 175.33 \\
\hline p19 & Unknown hydroxy diterpenoic acid B & D & G & n.d. & n.d. & n.d. & n.d. & n.d. & 69.30 & 62.09 \\
\hline p20 & Unknown hydroxy diterpenoic acid C & D & G & n.d. & n.d. & n.d. & n.d. & n.d. & 49.66 & 132.96 \\
\hline p21 & Unknown diterpenoid $\mathrm{A}$ & D & G & n.d. & n.d. & n.d. & n.d. & n.d. & 571.30 & 432.59 \\
\hline p22 & Dehydroabietic diacid methyester? & D & G & n.d. & n.d. & n.d. & n.d. & n.d. & 644.08 & 270.79 \\
\hline p23 & Campesterol & $S$ & $A, G$ & 0.39 & 0.04 & 0.05 & 0.18 & n.d. & 24.16 & 8.40 \\
\hline p24 & Stigmasterol & $S$ & $A, G$ & 0.34 & n.d. & n.d. & 0.15 & n.d. & 2.52 & n.d. \\
\hline p25 & $\beta$-Sitosterol & $S$ & $A, G$ & 3.98 & 0.41 & 0.69 & 1.63 & 14.15 & 167.70 & 77.83 \\
\hline p26 & Stigmastanol & $S$ & $A, G$ & 4.34 & 0.83 & 1.04 & 1.88 & 6.75 & 2.36 & 0.98 \\
\hline p27 & 3-Oxolupenoic acid & $\mathrm{T}$ & $A$ & n.d. & n.d. & n.d. & n.d. & 10.44 & n.d. & n.d. \\
\hline
\end{tabular}

n. d.: not detected. Type: D: Diterpenoid, S: Steroid, T: Triterpenoid.

Origin: A: Angiosperm, G: Gymnosperm 


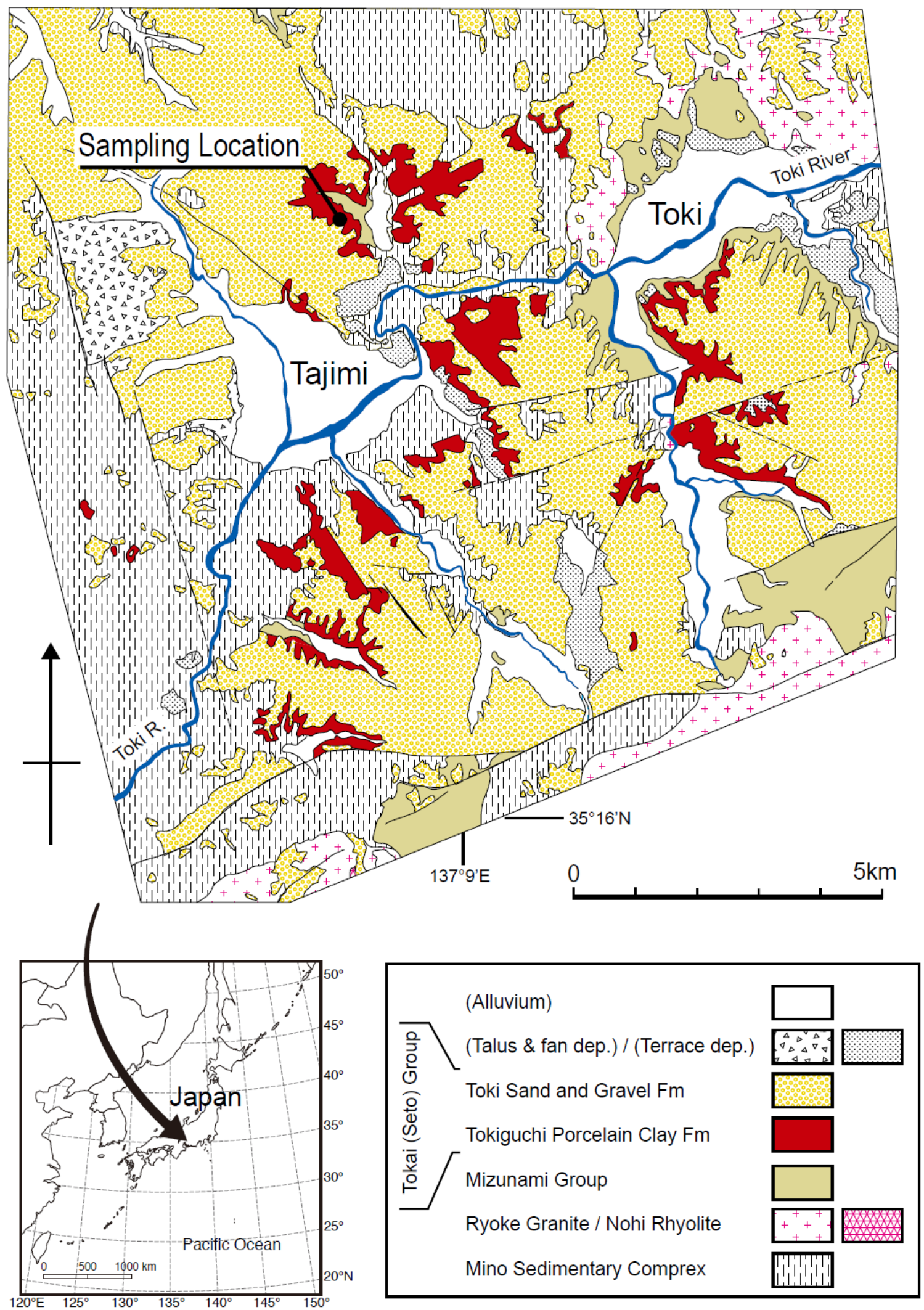

Figure 1 Location of the Okumura-Seram mine (Onada mine), and geological map of Tajimi area, central Japan (Todo Collaborative Research Group, 1999). 


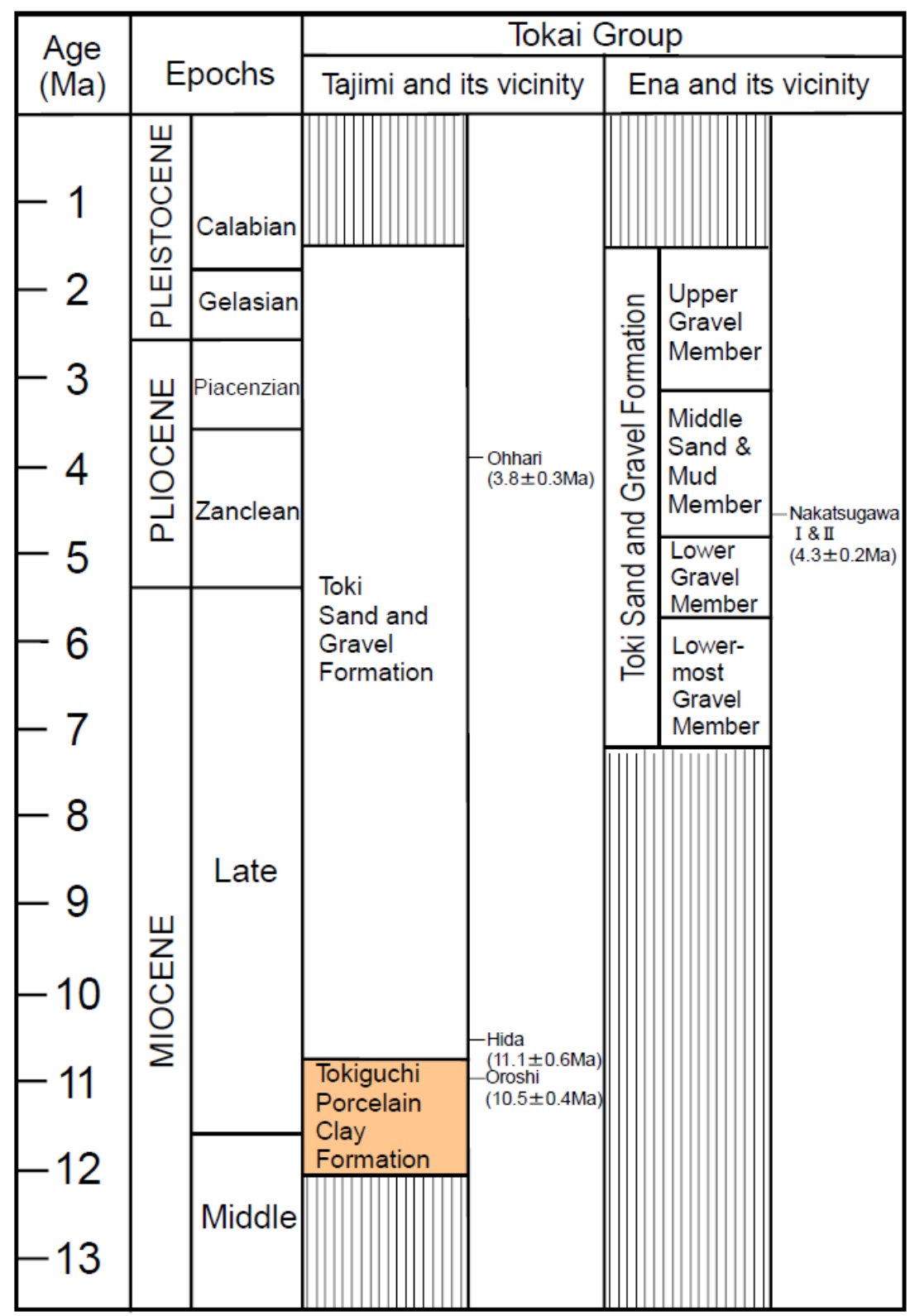

Figure 2 Stratigraphic and lithologic sections of the Tokai Group in Tajimi and Ena areas, central Japan (Todo Collaborative Research Group, 1999). Tuff beds and their fission track ages are also shown (Yoshida et al., 1997). 


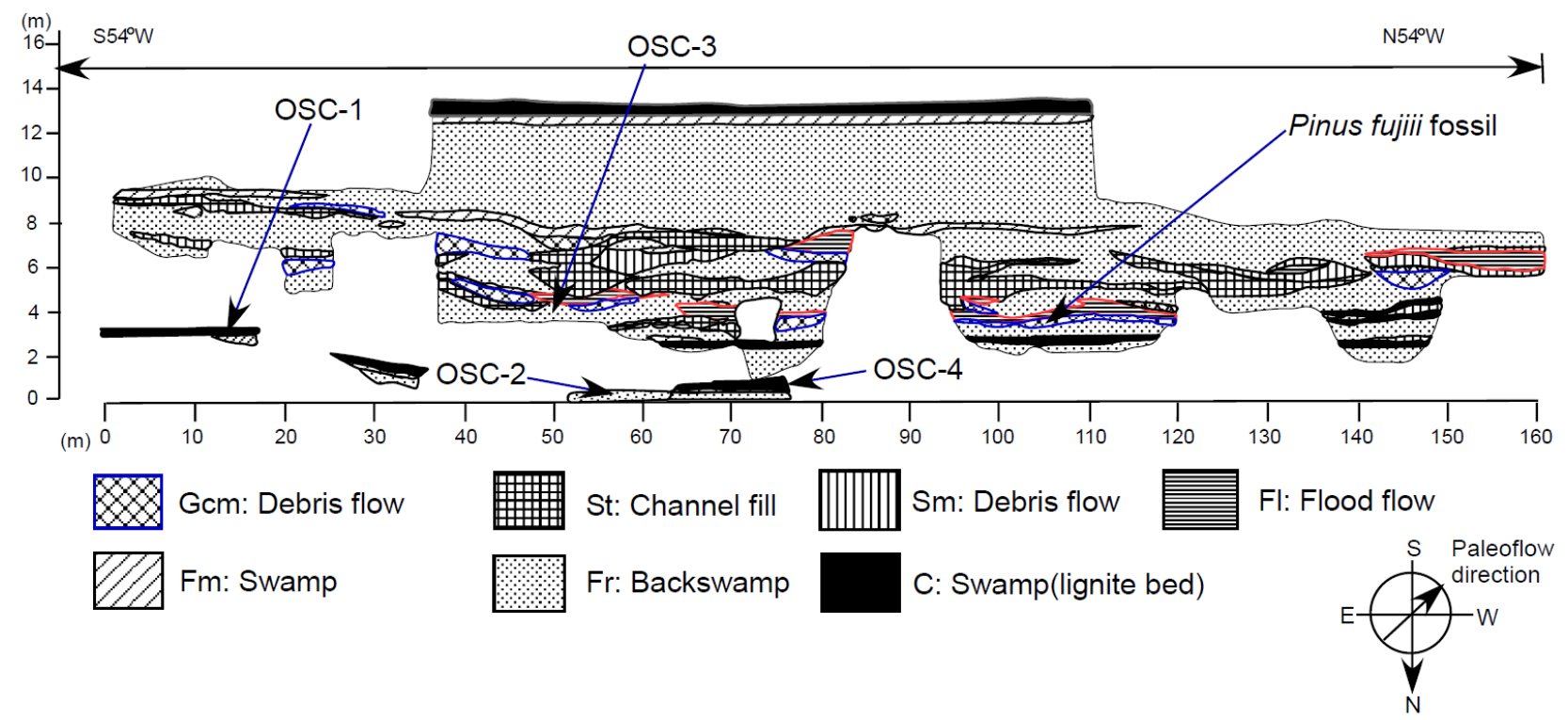

Figure 3 Sketch of an outcrop in the Okumura-Seram mine (Onada mine) of Tajimi City, central Japan, based on Saneyoshi et al. (2000). Sedimentary facies reported by Saneyoshi et al. (2000) is also shown. 


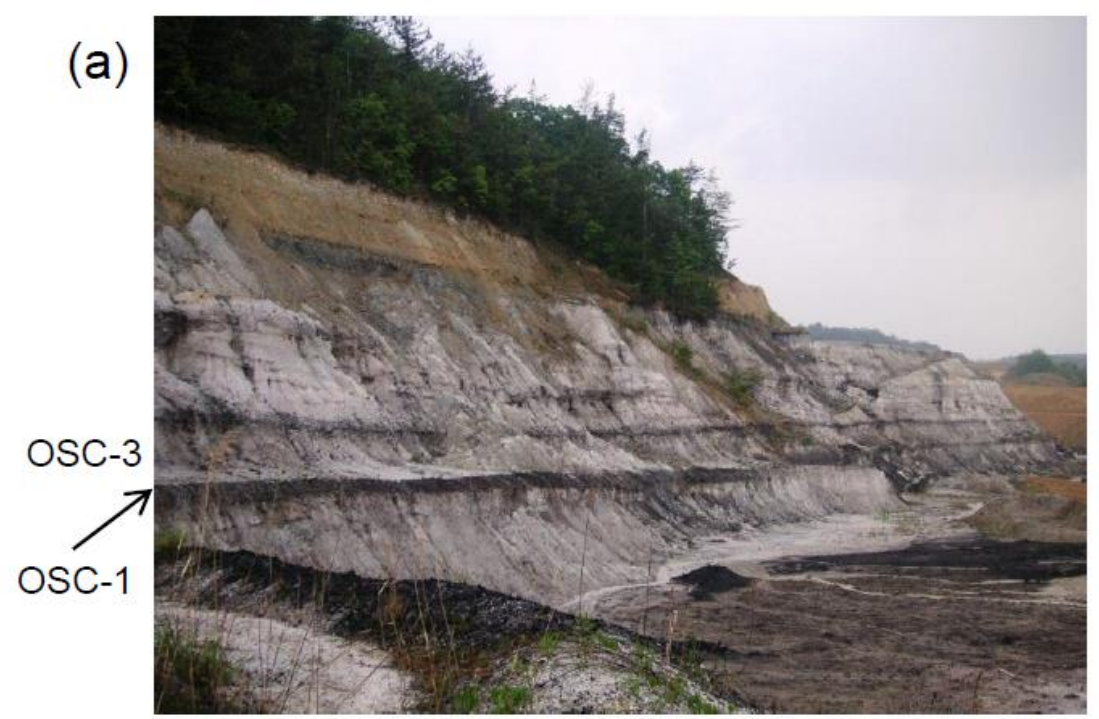

(b)

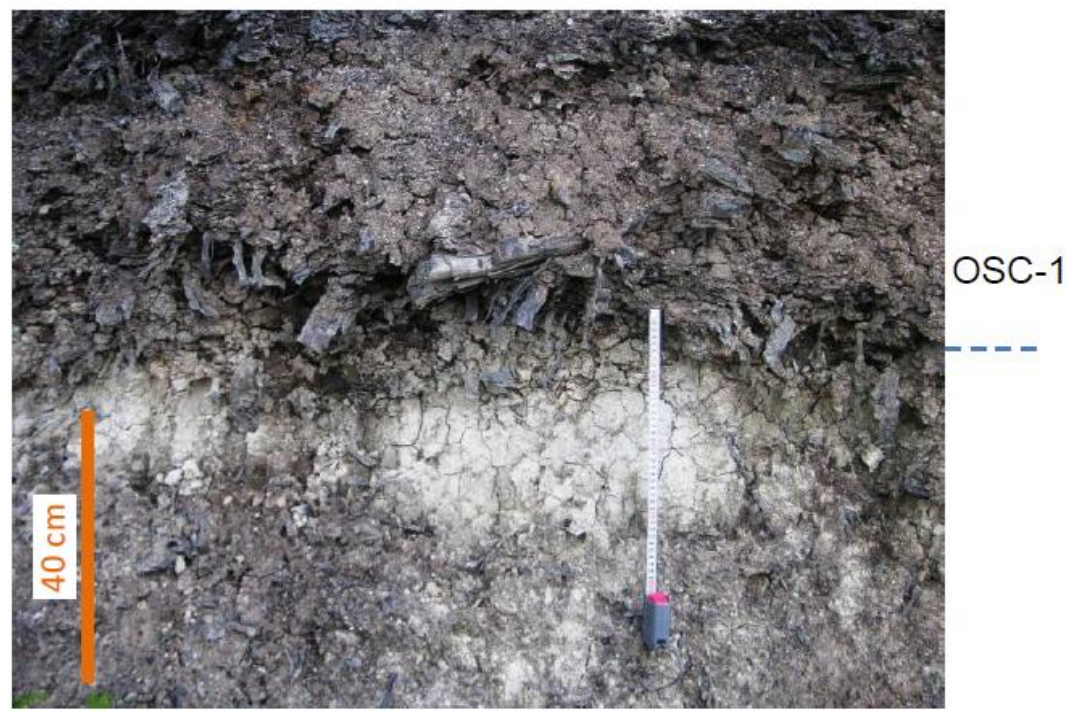

(c)

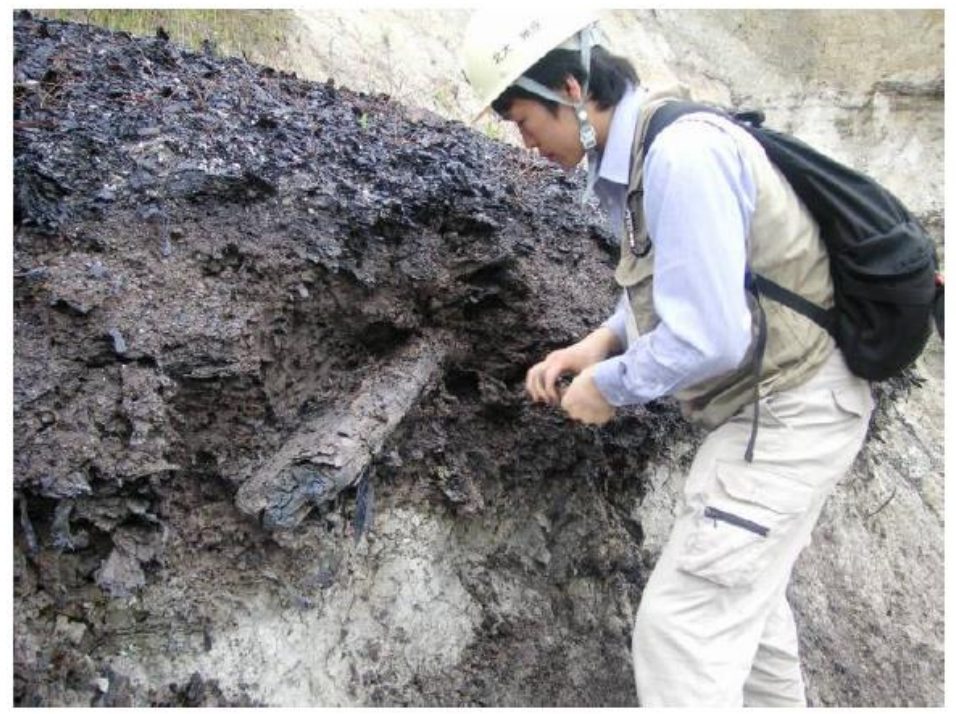

Figure 4 Photographs of (a) an outcrop of the Okumura-Seram mine (Onada mine) of Tajimi City, (b) lignite seam (OSC-1) and the below porcelain clay beds, and (c) wood (trunk) fossil in the lignite seam OSC-1. 


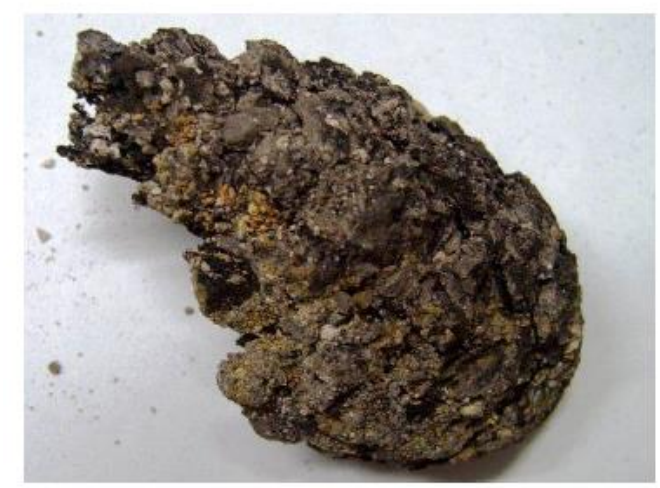

\section{$5 \mathrm{~cm}$}

\section{Fossil Pinus fujiii}

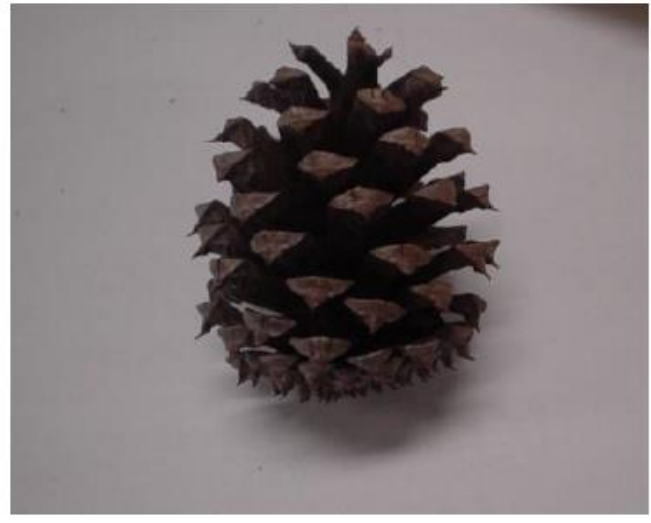

Extant Pinus rigida

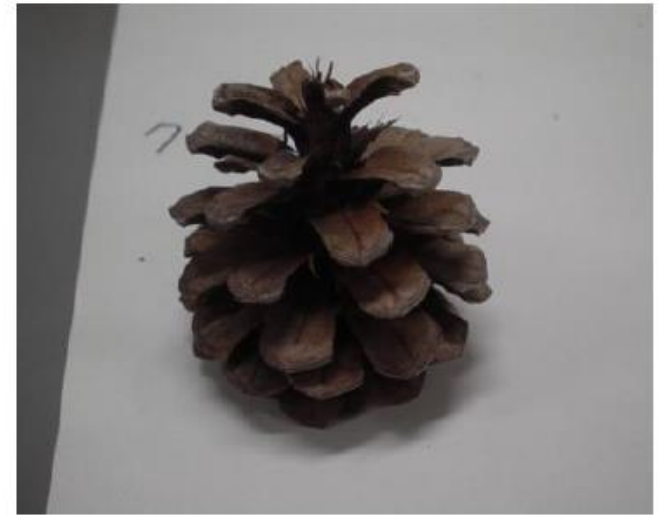

Extant Pinus thunbergii

Figure 5 Photographs of a conifer cone fossil ( $P$. fujiii) from the Okumura-Seram mine (Onada mine), and extant cones ( $P$. rigida and $P$. thunbergii). 
(a)

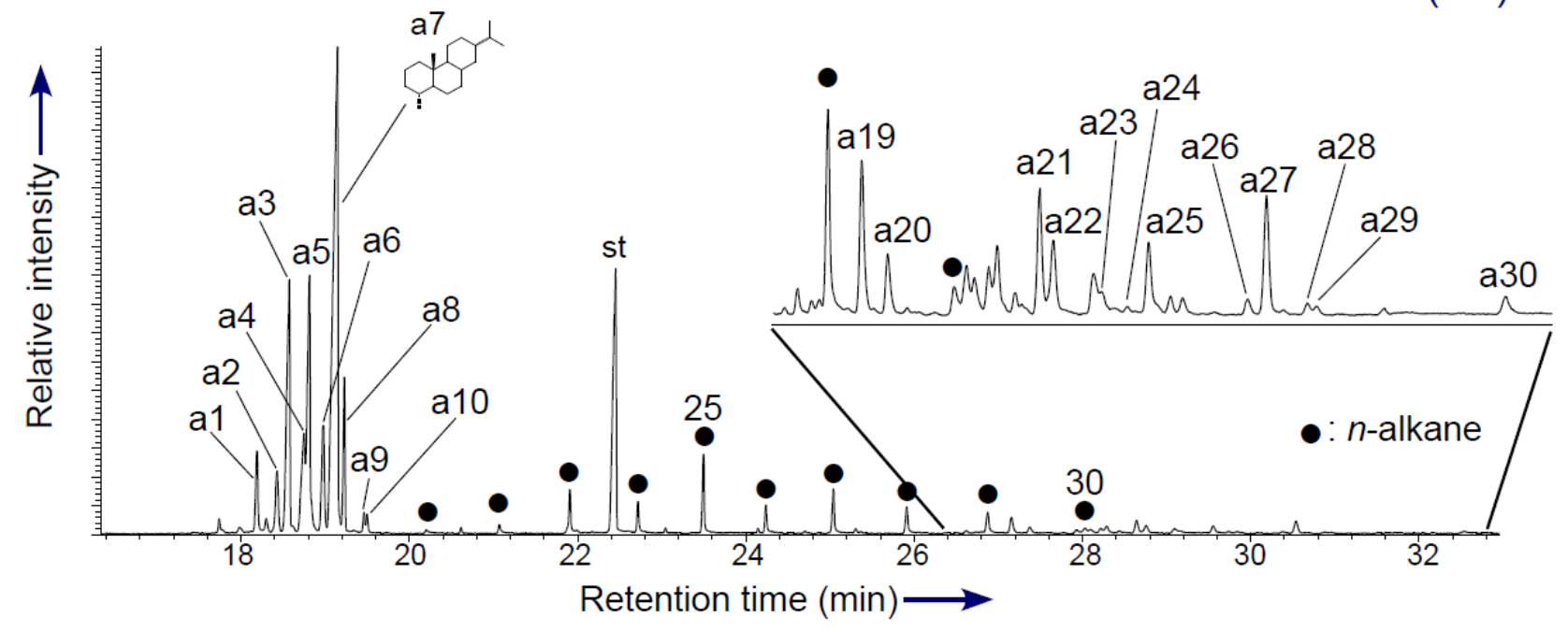

(b)

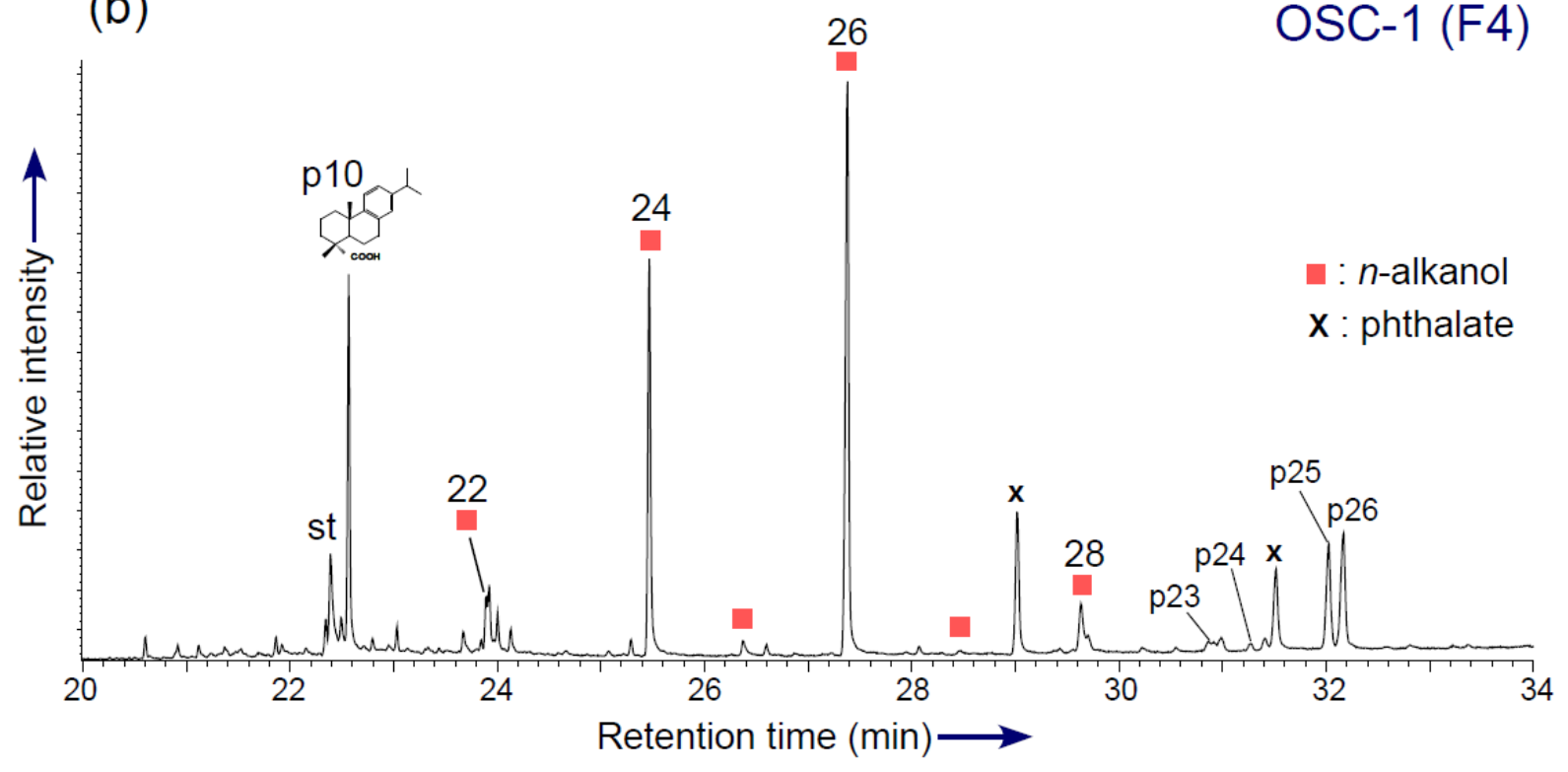

Figure 6 Partial ion chromatograms in (a) aliphatic (F1) and polar (F4) fractions of sediment from lignite seam OSC-1. st: internal standard. Numbers in (a) and (b) show carbon numbers of $n$-alkanes and $n$-alkanols, respectively. 
(a)

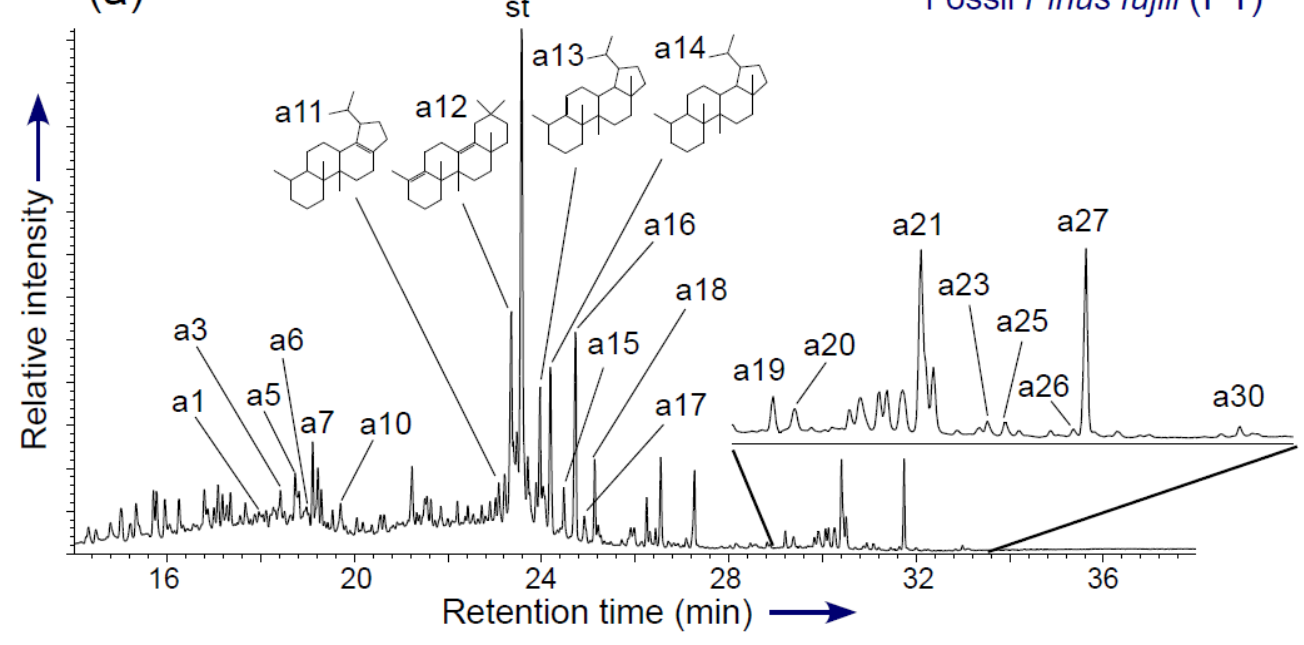

(b)
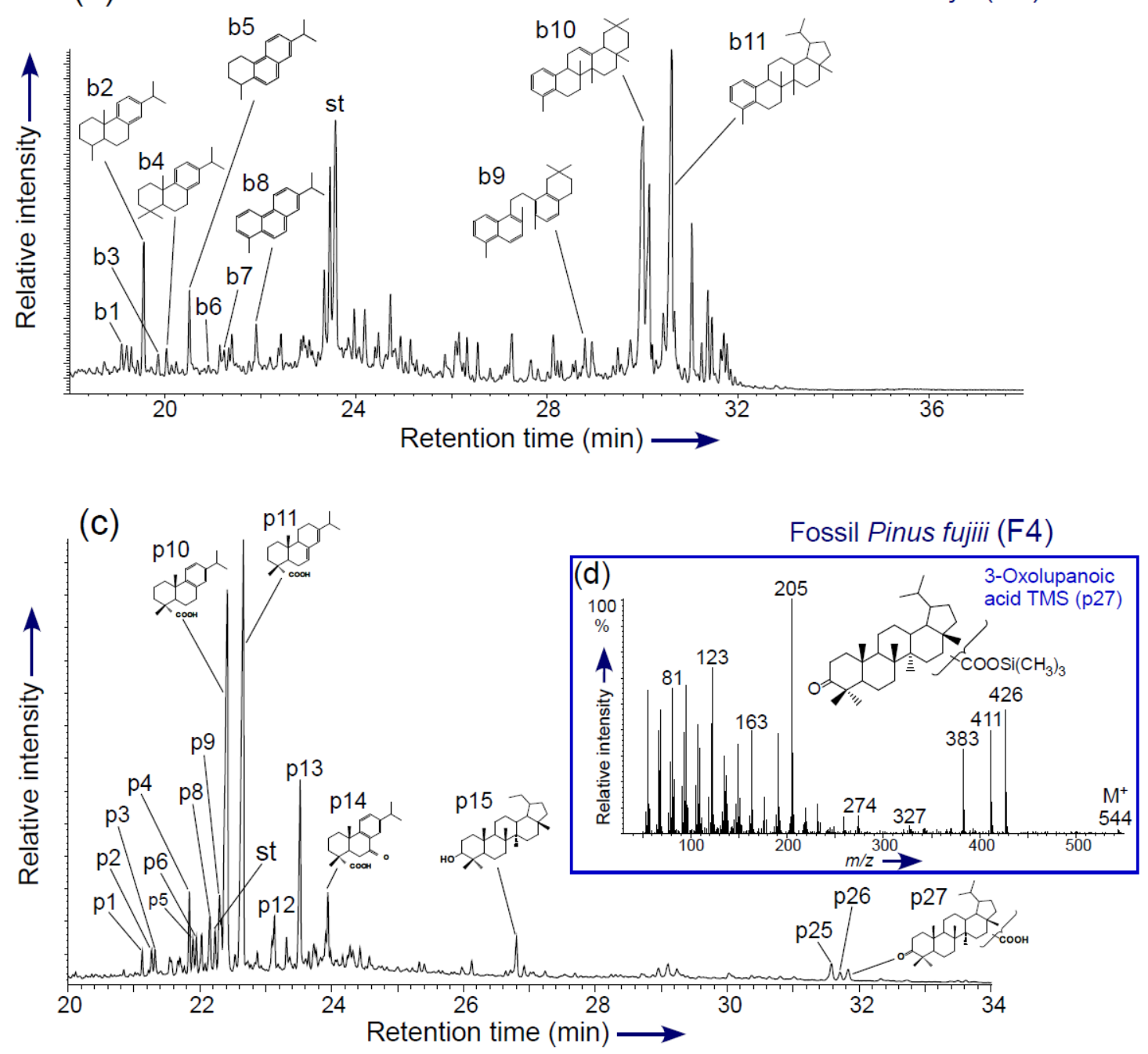

Figure 7 Partial ion chromatograms in (a) aliphatic (F1), (b) aromatic (F2) and (c) polar (F4) fractions of fossil $P$. fujiii, and (d) mass spectra of 3-oxolupanoic acid TMS (p27) in polar fractions (F4) of fossil P. fujiii. st: internal standard. 

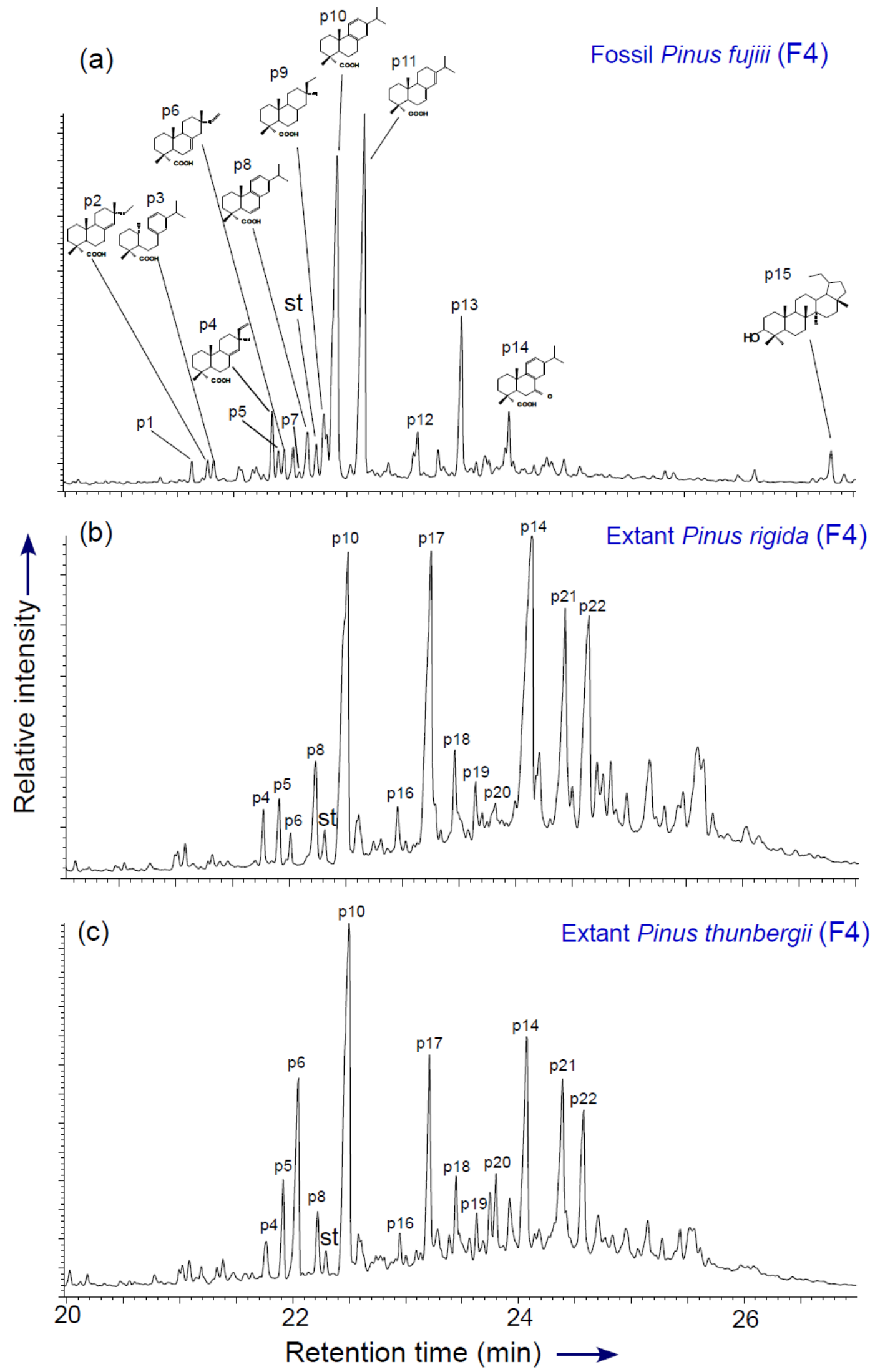

Figure 8 Partial ion chromatograms in polar fractions (F4) of fossil P. fujiii from the Onada mine, and extant cones P. rigida and P. thunbergii. 

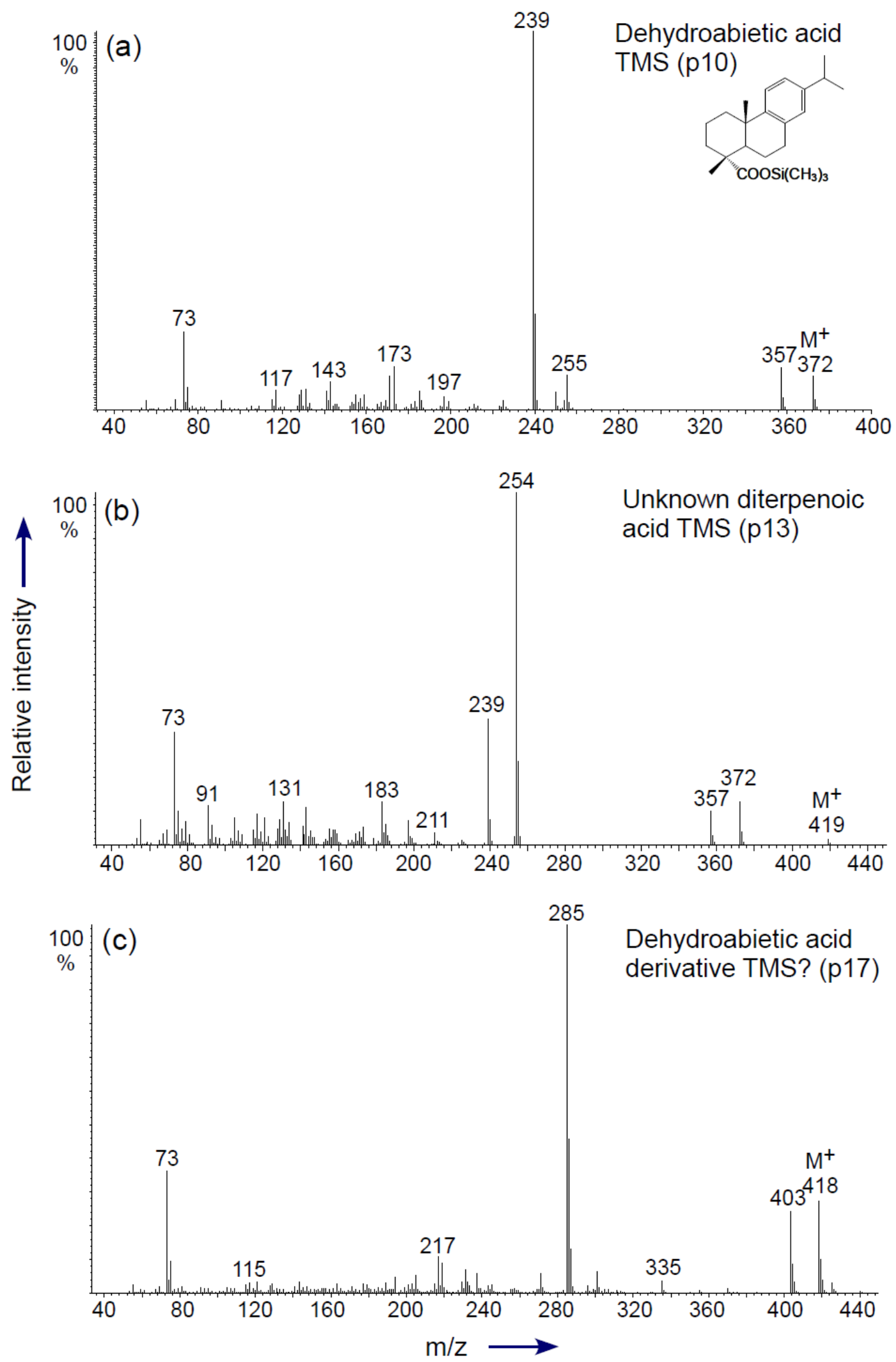

Figure 9 Mass spectra of terpenoid alcohol and acid in polar fractions (F4) of fossil P. fujii and extant cone P. rigida. (a) dehydroabietic acid TMS (p10 in Table 2 and Fig. 7), (b) unknown diterpenoic acid TMS (p13 in Table 2 and Fig. 7), and (c) dehydroabietic acid derivative TMS (p17 in Table 2 and Fig. 8). 

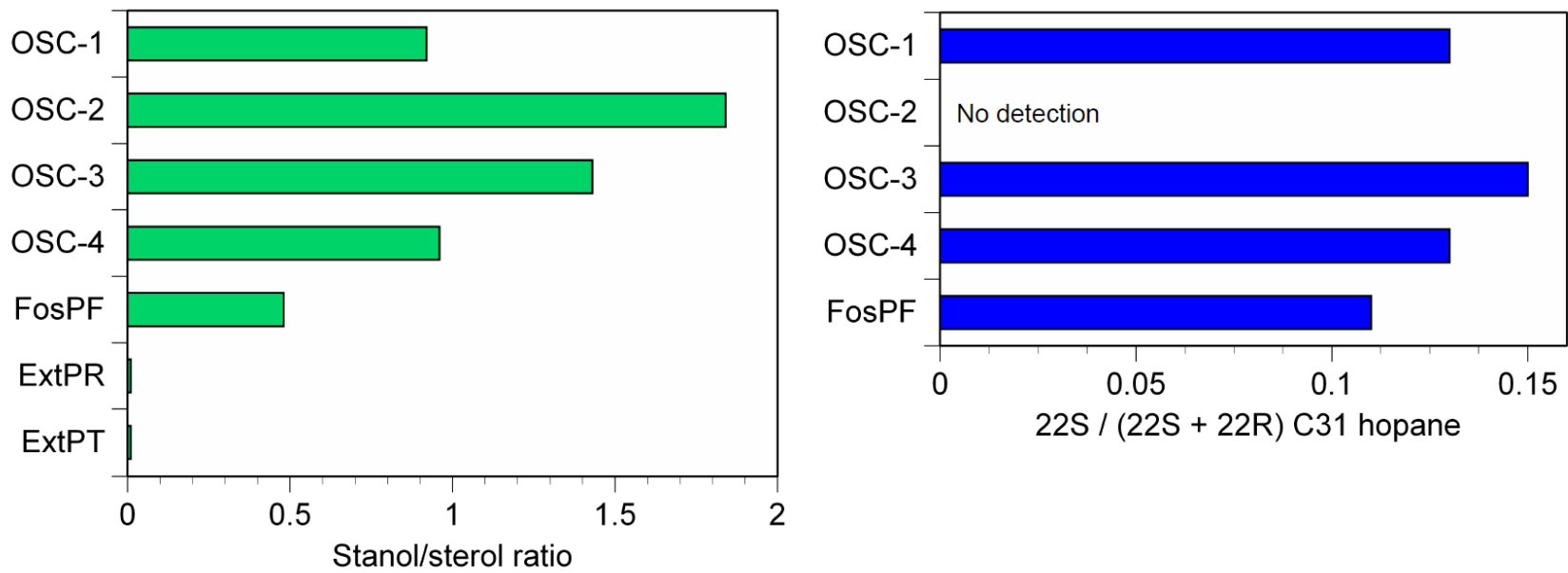

Figure $10 \mathrm{Stanol} / \mathrm{sterol}$ ratios and hopane isomer ratios such as $22 \mathrm{~S} /(22 \mathrm{~S}+22 \mathrm{R})$ ratios of $\mathrm{C}_{31}$ hopane (homohopane) of lignite-containing sediments and fossil $P$. fujiii from the Onada mine, and extant cones $P$. rigida and P. thunbergii. FosPF: fossil P. fujiii, ExtPR: extant cones P. rigida, and ExtPT: P. thunbergii. 